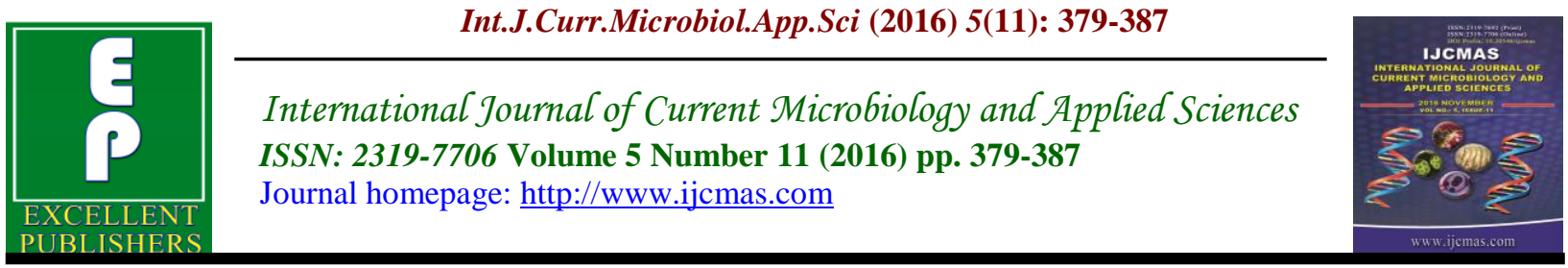

Original Research Article

http://dx.doi.org/10.20546/ijcmas.2016.511.043

\title{
Assessment of the Bacteriological Quality of an Aquatic Ecosystem in South of Benin: Case of Ahémé Lake
}

\author{
Pivot S.A. Sachi ${ }^{1 *}$, Innocent Yaou Bokossa ${ }^{1}$, Célestin C.K. Tchekessi ${ }^{1}$, Roseline M. \\ Bleoussi $^{1}$, Jultesse S.B. Banon ${ }^{1}$, Anayce A. Djogbe', Karl Assogba' and Guy A. Mensah ${ }^{2}$ \\ ${ }^{1}$ Unité de Recherche en Sécurité Sanitaire des Aliments (URSSA), Laboratoire de Microbiologie \\ et des Technologies Alimentaires (LAMITA), Département de Biologie Végétale, Faculté des \\ Sciences et Techniques (FAST), Université d'Abomey-Calavi (UAC), Cotonou, \\ République du Bénin \\ ${ }^{2}$ Institut National des Recherches Agricoles du Bénin (INRAB), Cotonou, République du Bénin \\ *Corresponding author
}

\begin{tabular}{|c|c|}
\hline & A B S T R A C T \\
\hline & \multirow{5}{*}{$\begin{array}{l}\text { The study aims to assess the bacteriological quality of water of the Ahémé lake, the } \\
\text { second most productive lake of Benin, after Nokoué lake. For this, } 21 \text { points were } \\
\text { sampled on the lake during two campaign periods during the year } 2016 \text { : the low } \\
\text { water period (March) and the flood period (September). A total of } 42 \text { water } \\
\text { samples were taken and their charges in total flora, thermotolerant and total } \\
\text { coliforms, Staphylococcus and Salmonella were determined. Despite the absence of } \\
\text { salmonella in all those withdrawn waters, average charges recorded in both periods } \\
\text { (low water period as flood period) for these counted germs were not consistent with } \\
\text { standards. Mean charges expressed in CFU/mL of the total flora, total and } \\
\text { thermotolerant coliforms and staphylococci recorded at low water were } \\
\text { respectively of } 19.69 .10^{8} \text {, } 17.49 .10^{5}, 12.07 .10^{5} \text { and } 12.40 .10^{3} \text {. These values } \\
\text { increased and reached respectively } 29.56 .10^{8}, 22.41 .10^{5}, 15.84 .10^{5} \text { and } 27.53 .10^{3} \\
\text { during the flood. Waters of Ahémé lake are considerably loaded with germs of } \\
\text { fecal contamination. This lake pollution affects the quality of fishery products in it } \\
\text { and perhaps also a potential source of disease. }\end{array}$} \\
\hline & \\
\hline crobiological & \\
\hline Info & \\
\hline onted. & \\
\hline
\end{tabular}

\section{Introduction}

Water is the basis of all the life. It is at same time the habitat, food, means of production in the agricultural sector as in industry, transport route for people and goods, therefore indirectly it is a commercial product (Dovonou et al., 2011). Such is the case of the waters of Lake Ahémé, the second largest lake in Benin which serves as dwelling place for lake people whose principal income generating activity is fishing) (Dègnon et al., 2012; Adigun, 2013).

In consideration of the socio-economic importance of Lake Ahémé, a high concentration of the population is noted in and around this lake. These people reject daily, the solid and liquid wastes which 
come from their various activities in the lake or on the banks. The throwing out of the urban waters which come from the waterside agglomerations and the contributions of Couffo river, are also sources of contamination of the ecosystem (Dimon et al., 2014).

In addition, within the context of their fishing activities, large quantities of branches for the fish traps construction commonly called "acadjas" are routinely abandoned or dumped by fishermen in the water (Dovonou et al., 2011; Sachi et al., 2016).

The lake is facing serious environmental problems including pollution (Agonkpahoun, 2006; Dimon et al., 2014). What may be the cause of the disappearance of certain animal aquatic species and/or plant and therefore carry away the malfunctions of the food chain (Dimon et al., 2014).

The objective of the study is to assess the bacteriological quality of the lake water Ahémé by determining of their mean loads in total flora, thermotolerant and total coliforms, staphylococcus and salmonella.

\section{Materials and Methods}

\section{Frames of the study}

The geographic cadre of this study is Lake Ahémé (Figure). It is located in southwestern of Benin. Between the parallel $6^{\circ} 20^{\prime}$ 'and $6^{\circ} 40^{\prime}$ North and meridians $1^{\circ}$ $55^{\prime}$ and $2^{\circ}$ East and with approximately an area of $80 \mathrm{~km} 2$ at low water, it stretches between Topka-Domé and Guézin according to the North-East-South-West direction and between Topka-Domé and Bopa following the North-South direction. It serves as a natural boundary between the departments of Mono and Atlantic. Ahémé the lake is a valley that receives Couffo river waters in the northern part and is connected to the coastal lagoon of Grand-Popo by the channel called "Aho" (Niyonkuru and Lalèyê, 2012; Dèdjiho, 2014).

Microbiological analyzes were done in the Laboratory of Microbiology and Food Technology (LA.MI.TA.) based in Cotonou (Benin).

\section{Materials}

Several materials were used in this study as: the field materials which include a GPS (to identify sampling points), $1 \mathrm{~L}$ bottles of sterilized water ballasted (for sample collection), an icebox with icicles (for storing samples), a water analysis suitcase including a digital peak thermometer $\left(-50^{\circ}\right.$ $\mathrm{C}$ to $150^{\circ} \mathrm{C}$ to measure the temperature of the water) and an electronic $\mathrm{pH}$ meter (Hanna Instruments HI 96107) previously calibrated with buffer solutions of $\mathrm{pH} 4.1$ and 7.1 for measuring the $\mathrm{pH}$ of water; mineral material consisting essentially of the drawn water samples; and standard laboratory equipment used for various microbiological analyzes.

\section{Sampling}

The data for this study come from 21 sampling points on the lake Ahémé symbolized P1 to P21 (Figure) whose geographical coordinates are presented in Table 1. These sampling points are obtained after the Lake mesh. The size of a mesh is 4 $\mathrm{km}^{2}$ and vertex of each mesh constituted our water sampling sites. Two sampling campaigns were conducted. A first campaign unrolled during the low water period in March 2016 and a second during the flood period in September 2016. A total of 42 water samples were taken. Bottles of 
1L of ballasted water sterilized and provided of a rope have been used in order to draw water in depth. The samples have been named carefully with all necessary information and have immediately been routed to the laboratory in an icebox with ice.

\section{Assessment of microbiological quality}

Microbiological analysis consisted in counting the total mesophilic flora on PCA (Oxoid CM 0325) incubated at $30^{\circ} \mathrm{C}$ during 48 to $72 \mathrm{~h}$ (NFV 08-051); total coliforms (NFV 08-060) and thermotolerant coliforms (NFV 08-050) on VRBA-Oxoid CM 0107 (Violet Red Bile Agar) incubated respectivelly at $37^{\circ} \mathrm{C}$ and at $44^{\circ} \mathrm{C}$ during 24 h; Staphylococcus on Baird Parker Agar (BP-Oxoid CM 0275) at egg yolk and potassium tellurite incubated at $37^{\circ} \mathrm{C}$ during $24 \mathrm{~h}$ (NFV 08-057-1) and Salmonella (NF EN ISO 6579) on SS Agar according to the following stages: pre enrichment (incubation solutions mothers at $37^{\circ} \mathrm{C}$ for $20 \mathrm{~h}$ ); on enrichment broths Muller Koffman incubated at $37^{\circ} \mathrm{C}$ for $24 \mathrm{~h}$ and Rappaport Vassiliadis incubated at $37^{\circ} \mathrm{C}$ for 24 hours; isolation on Hektoen agar and incubated at $37^{\circ} \mathrm{C}$ for $24 \mathrm{~h}$ and Xylose Lysine Deoxycholate Agar (XLD) incubated at $41^{\circ} \mathrm{C}$ for $24 \mathrm{~h}$; identifying on the urea-indole medium at $37^{\circ} \mathrm{C}$ for $2 \mathrm{~h}$. The counting was done by counting the colonies (Guiraud and Galzy, 1980). Microbiological analyzes were performed in triplicate on each sample.

\section{Statistical analyzes of data}

The Excel software was used to perform the calculations. Analysis results were processed using Minitab 16.0 software that permitted to make analysis of variance (ANOVA) and Tukey's test for comparison of means. The significance level of $5 \%$ is selected $(\mathrm{p}<0.05)$.

\section{Results and Discussion}

\section{Physicochemical parameters}

The mean values of the temperature and $\mathrm{pH}$ of the water obtained on the lake were shown in Table 2.

The mean values of $\mathrm{pH}$ recorded were between 7.80 and 8.45 during the low water and between 6.55 and 7.25 during floods. For all sampling sites, the average $\mathrm{pH}$ of the water obtained during low water was higher than that recorded during the flood period and the difference was 1.23 (Table 2). Similarly, the mean values of the recorded temperature ranged between 28.50 and $29.15^{\circ} \mathrm{C}$ at low water and between 27.0 and $27.75^{\circ} \mathrm{C}$ during floods. For all sampling sites on the lake, its average temperature during the low water period was higher than that recorded during the flood period and the difference between these two averages was $1.50^{\circ} \mathrm{C}$ (Table 2).

\section{Microbiological parameters}

Tables 3 and 4 presented the results of bacteriological analyzes of water taken at different points of the lake respectively during low water and flood.

In low water as in flood, a major significant difference ( $p>0.05)$ was observed between the mean charges obtained at different sampling sites for the total flora, staphylococcus and total coliforms and thermotolerant except for salmonella which noted the total absence in $25 \mathrm{~mL}$ of all water samples.

The mean charges of the total flora obtained ranged $14.92 .10^{8}$ and $24.74 .10^{8} \mathrm{CFU} / \mathrm{mL}$ during low water and between $24.22 .10^{8}$ and 35.29.10 ${ }^{8} \mathrm{CFU} / \mathrm{mL}$ during the flood. For all sampling points, the mean concentration of 
total flora resulting flood was 1.5 times higher than that obtained at low water.

The mean concentrations of total coliforms were obtained between $11.88 .10^{5}$ and 23.36.10 $\mathrm{CFU} / \mathrm{mL}$ during low water and between $14.37 .10^{5}$ and $28.61 .10^{5} \mathrm{CFU} / \mathrm{mL}$ during the flood. The mean charge for all sampling points obtained during the flood was greater than that recorded during the low water and the difference between these two means was $4.92 .10^{5} \mathrm{CFU} / \mathrm{mL}$.

Mean charges thermotolerant coliform obtained ranged 7.16.10 5 and $16.65 .10^{5} \mathrm{CFU}$ / $\mathrm{mL}$ during low water and between 9.27.10 and $22.61 .10^{5} \mathrm{CFU} / \mathrm{mL}$ during the flood. For all sampling points, the mean concentration of total flora resulting flood was higher than that obtained by low water and the difference between these two averages was 3.77.10 ${ }^{5} \mathrm{CFU} / \mathrm{mL}$.

The mean concentrations of staphylococcus obtained ranged $9.85 .10^{3}$ and $15.23 .10^{3} \mathrm{CFU}$ / $\mathrm{mL}$ at low water and between $22.50 .10^{3}$ and 31.61.103 CFU/mL during the flood. For all sampling points, the mean concentration of staphylococcus obtained by flood was 2.22 times higher than that obtained at low water.

The mean values of water temperatures recorded on the lake showed that in times of low water as in the flood period (Table 2) are consistent with those of Abu (2001) and Dèdjiho (2014) which found that temperatures between 24 and $35{ }^{\circ} \mathrm{C}$ are favorable for good growth of commonly bred fish species. These temperatures are above $15{ }^{\circ} \mathrm{C}$, also favor the development of microorganisms (Rodier et al., 1996 cited by Adjahouinou et al., 2014).

Similarly, the mean values of water $\mathrm{pH}$ obtained on the lake showed that in times of low water as in the flood period (Table 2) are favorable for aquaculture because they are between 6.5 and 9 (Kanagire 2001; Dèdjiho, 2014) and also support the growth of microorganisms (Mara, 1980 quoted by Adjahouinou et al., 2014).

Comparison with standards (Directive of the Council of European Communities of 16 June 1975 cited by Servais et al., 2010) different means charges obtained after counting microbial germs shows that all these means charges are much higher than the standards required excepted salmonella (Table 3). These obtained mean charges are much higher than those obtained by Dovonou et al., (2011) and Mégnon et al., (2012) on Lake Nokoué, by Adigun (2013) on Nokoué and Ahémé lakes and the lagoon of Porto-Novo.

High loads of the total flora in the lake are due to the many activities of the local communities and around the lake; discharges of household rubbish and waste in the lake and the banks which are drained later in the lake by runoff and finally to the contributions of its tributaries (Couffo river, coastal lagoon of Grand-Popo) and collectors waste water surrounding communities especially in the rainy season (flood period).

The presence of total coliforms and thermotolerant in waters confirms the noncompliance with hygiene rules by the local population because coliforms are the work of fecal contamination of both men and animals. This is due to the low use of latrines by these populations and unhealthy breeding practices as highlighted the work of Sachi et al., (2016) on Lake Nokoué.

These observations show that the lake Ahémé is extremely polluted by microbial germs. 
Fig.1 Card of Ahémé lake with the points of withdrawal of the water samples (Sachi, 2015)

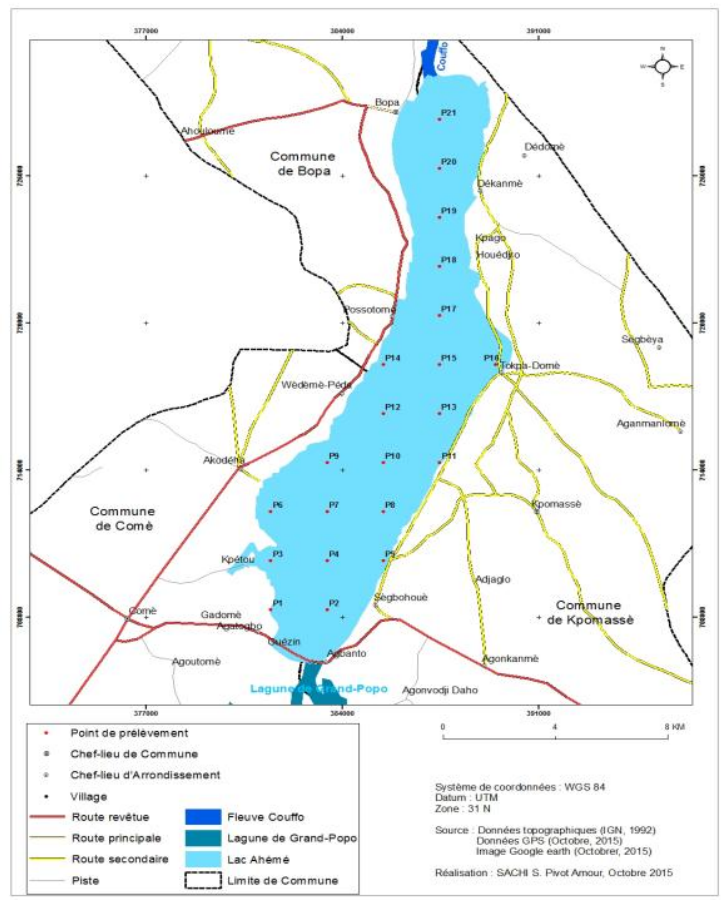

Table.1 Geographical coordinates of the different points of sampling

\begin{tabular}{ccc}
\hline Points & Longitudes $(\mathrm{m})$ & Latitudes $(\mathrm{m})$ \\
\hline P1 & 381475.4964 & 708309.156 \\
P2 & 383475.4964 & 708309.156 \\
P3 & 381475.4964 & 710309.156 \\
P4 & 383475.4964 & 710309.156 \\
P5 & 385475.4964 & 710309.156 \\
P6 & 381475.4964 & 712309.156 \\
P7 & 383475.4964 & 712309.156 \\
P8 & 385475.4964 & 712309.156 \\
P9 & 383475.4964 & 714309.156 \\
P10 & 385475.4964 & 714309.156 \\
P11 & 387475.4964 & 714309.156 \\
P12 & 385475.4964 & 716309.156 \\
P13 & 387475.4964 & 716309.156 \\
P14 & 385475.4964 & 718309.156 \\
P15 & 387475.4964 & 718309.156 \\
P16 & 389475.4964 & 718309.156 \\
P17 & 387475.4964 & 720309.156 \\
P18 & 387475.4964 & 722309.156 \\
P19 & 387475.4964 & 724309.156 \\
P20 & 387475.4964 & 726309.156 \\
P21 & 387475.4964 & 728309.156 \\
\hline
\end{tabular}


Table.2 Mean values of temperature and $\mathrm{pH}$ of the drawn water samples

\begin{tabular}{ccccc}
\hline Points & \multicolumn{2}{c}{ Temperature $\left({ }^{\circ} \mathrm{C}\right)$} & \multicolumn{2}{c}{$\mathrm{pH}$} \\
\cline { 2 - 5 } P1 & Low water period & Flood period & Low water period & Flood period \\
P2 & $28.65 \pm 0.070^{\mathrm{a}}$ & $27.00 \pm 0.000^{\mathrm{a}}$ & $7.85 \pm 0.070^{\mathrm{a}}$ & $6.60 \pm 0.000^{\mathrm{a}}$ \\
P3 & $28.80 \pm 0.000^{\mathrm{a}}$ & $27.35 \pm 0.070^{\mathrm{b}}$ & $8.05 \pm 0.070^{\mathrm{a}}$ & $6.75 \pm 0.070^{\mathrm{a}}$ \\
P4 & $28.70 \pm 0.000^{\mathrm{a}}$ & $27.10 \pm 0.000^{\mathrm{a}}$ & $7.90 \pm 0.000^{\mathrm{a}}$ & $6.65 \pm 0.070^{\mathrm{a}}$ \\
P5 & $29.05 \pm 0.070^{\mathrm{b}}$ & $27.45 \pm 0.070^{\mathrm{b}}$ & $8.10 \pm 0.000^{\mathrm{b}}$ & $6.80 \pm 0.000^{\mathrm{a}}$ \\
P6 & $28.55 \pm 0.070^{\mathrm{a}}$ & $27.05 \pm 0.070^{\mathrm{a}}$ & $7.80 \pm 0.000^{\mathrm{a}}$ & $6.55 \pm 0.070^{\mathrm{a}}$ \\
P7 & $28.65 \pm 0.070^{\mathrm{a}}$ & $27.15 \pm 0.070^{\mathrm{a}}$ & $7.95 \pm 0.070^{\mathrm{a}}$ & $6.80 \pm 0.000^{\mathrm{a}}$ \\
P8 & $29.10 \pm 0.000^{\mathrm{b}}$ & $27.50 \pm 0.000^{\mathrm{b}}$ & $8.25 \pm 0.070^{\mathrm{b}}$ & $6.95 \pm 0.070^{\mathrm{b}}$ \\
P9 & $29.05 \pm 0.070^{\mathrm{b}}$ & $27.40 \pm 0.000^{\mathrm{b}}$ & $8.15 \pm 0.070^{\mathrm{b}}$ & $6.85 \pm 0.070^{\mathrm{b}}$ \\
P10 & $28.70 \pm 0.000^{\mathrm{a}}$ & $27.25 \pm 0.070^{\mathrm{b}}$ & $8.05 \pm 0.070^{\mathrm{a}}$ & $6.75 \pm 0.070^{\mathrm{a}}$ \\
P11 & $29.15 \pm 0.070^{\mathrm{b}}$ & $27.75 \pm 0.070^{\mathrm{c}}$ & $8.40 \pm 0.000^{\mathrm{c}}$ & $7.25 \pm 0.070^{\mathrm{c}}$ \\
P12 & $28.50 \pm 0.000^{\mathrm{a}}$ & $27.05 \pm 0.070^{\mathrm{a}}$ & $8.15 \pm 0.070^{\mathrm{b}}$ & $6.85 \pm 0.070^{\mathrm{b}}$ \\
P13 & $29.00 \pm 0.000^{\mathrm{b}}$ & $27.60 \pm 0.000^{\mathrm{c}}$ & $8.30 \pm 0.000^{\mathrm{c}}$ & $7.15 \pm 0.070^{\mathrm{c}}$ \\
P14 & $28.95 \pm 0.070^{\mathrm{a}}$ & $27.55 \pm 0.070^{\mathrm{b}}$ & $8.15 \pm 0.070^{\mathrm{b}}$ & $6.95 \pm 0.070^{\mathrm{b}}$ \\
P15 & $28.85 \pm 0.070^{\mathrm{a}}$ & $27.20 \pm 0.000^{\mathrm{b}}$ & $8.05 \pm 0.070^{\mathrm{a}}$ & $6.75 \pm 0.070^{\mathrm{a}}$ \\
P16 & $29.00 \pm 0.000^{\mathrm{b}}$ & $27.65 \pm 0.070^{\mathrm{c}}$ & $8.45 \pm 0.070^{\mathrm{d}}$ & $7.25 \pm 0.070^{\mathrm{c}}$ \\
P17 & $28.85 \pm 0.070^{\mathrm{a}}$ & $27.25 \pm 0.070^{\mathrm{b}}$ & $7.95 \pm 0.070^{\mathrm{a}}$ & $6.75 \pm 0.070^{\mathrm{a}}$ \\
P18 & $28.95 \pm 0.070^{\mathrm{a}}$ & $27.50 \pm 0.000^{\mathrm{b}}$ & $8.35 \pm 0.070^{\mathrm{c}}$ & $7.20 \pm 0.000^{\mathrm{c}}$ \\
P19 & $28.95 \pm 0.070^{\mathrm{a}}$ & $27.45 \pm 0.070^{\mathrm{b}}$ & $8.30 \pm 0.000^{\mathrm{c}}$ & $7.05 \pm 0.070^{\mathrm{b}}$ \\
P20 & $28.85 \pm 0.070^{\mathrm{a}}$ & $27.40 \pm 0.000^{\mathrm{b}}$ & $8.15 \pm 0.070^{\mathrm{b}}$ & $6.95 \pm 0.070^{\mathrm{b}}$ \\
P21 & $28.80 \pm 0.000^{\mathrm{a}}$ & $27.35 \pm 0.070^{\mathrm{b}}$ & $8.05 \pm 0.070^{\mathrm{a}}$ & $6.85 \pm 0.070^{\mathrm{b}}$ \\
Means & $28.75 \pm 0.070^{\mathrm{a}}$ & $27.20 \pm 0.000^{\mathrm{b}}$ & $7.90 \pm 0.000^{\mathrm{a}}$ & $6.80 \pm 0.000^{\mathrm{a}}$ \\
\hline
\end{tabular}

Mean values with the same letter on the same line and in the same column are not significantly different at the $5 \%$ level. Data represents in table is mean of three replications. \pm Standard deviation.

Table.3 Mean values in CFU/mL of the germs counted in the samples of water during the period of low water

\begin{tabular}{|c|c|c|c|c|c|}
\hline Points & $\begin{array}{c}\text { Total mesophilic } \\
\text { flora }\left(\mathbf{1 0}^{\mathbf{8}}\right)\end{array}$ & $\begin{array}{c}\text { Total } \\
\text { coliforms }\left(10^{5}\right)\end{array}$ & $\begin{array}{l}\text { Thermotolerant } \\
\text { coliforms }\left(\mathbf{1 0}^{5}\right)\end{array}$ & $\begin{array}{c}\text { Staphylococcus } \\
\left(\mathbf{1 0}^{3}\right)\end{array}$ & Salmonella/25mL \\
\hline$\overline{\mathrm{P} 1}$ & $24.740 \pm 0.170^{\mathrm{a}}$ & $23.360 \pm 0.113^{\mathrm{a}}$ & $16.350 \pm 0.156^{\mathrm{a}}$ & $15.230 \pm 0.042^{\mathrm{a}}$ & Absent \\
\hline $\mathrm{P} 2$ & $21.340 \pm 0.170^{\mathrm{b}}$ & $18.300 \pm 0.042^{b}$ & $13.360 \pm 0.127^{\mathrm{b}}$ & $14.110 \pm 0.099^{b}$ & Absent \\
\hline P3 & $22.120 \pm 0.042^{c}$ & $21.650 \pm 0.127^{\mathrm{c}}$ & $15.790 \pm 0.113^{\mathrm{a}}$ & $14.900 \pm 0.056^{\mathrm{c}}$ & Absent \\
\hline P4 & $17.565 \pm 0.177^{\mathrm{d}}$ & $11.880 \pm 0.056^{\mathrm{d}}$ & $9.630 \pm 0.127^{\mathrm{c}}$ & $10.290 \pm 0.084^{\mathrm{d}}$ & Absent \\
\hline P5 & $22.140 \pm 0.127^{\mathrm{c}}$ & $20.720 \pm 0.042^{\mathrm{e}}$ & $15.950 \pm 0.099^{\mathrm{a}}$ & $15.020 \pm 0.056^{\mathrm{ce}}$ & Absent \\
\hline P6 & $19.695 \pm 0.035^{\mathrm{e}}$ & $22.440 \pm 0.170^{\mathrm{f}}$ & $14.750 \pm 0.127^{\mathrm{d}}$ & $13.800 \pm 0.028^{b}$ & Absent \\
\hline P7 & $14.920 \pm 0.085^{\mathrm{f}}$ & $12.550 \pm 0.099^{\mathrm{g}}$ & $7.160 \pm 0.113^{\mathrm{e}}$ & $9.850 \pm 0.113^{\mathrm{f}}$ & Absent \\
\hline P8 & $18.440 \pm 0.042^{\mathrm{g}}$ & $14.240 \pm 0.099^{\mathrm{h}}$ & $8.840 \pm 0.099^{\mathrm{f}}$ & $10.500 \pm 0.056^{\mathrm{dg}}$ & Absent \\
\hline P9 & $16.675 \pm 0.134^{\mathrm{h}}$ & $15.810 \pm 0.085^{\mathrm{i}}$ & $10.420 \pm 0.057^{\mathrm{g}}$ & $11.080 \pm 0.070^{\mathrm{h}}$ & Absent \\
\hline P10 & $15.670 \pm 0.057^{\mathrm{i}}$ & $13.170 \pm 0.056^{\mathrm{j}}$ & $7.900 \pm 0.113^{\mathrm{h}}$ & $10.080 \pm 0.042^{\mathrm{df}}$ & Absent \\
\hline P11 & $24.010 \pm 0.099^{j}$ & $19.260 \pm 0.170^{\mathrm{k}}$ & $12.710 \pm 0.099^{\mathrm{i}}$ & $12.390 \pm 0.028^{\mathrm{i}}$ & Absent \\
\hline P12 & $16.250 \pm 0.099^{\mathrm{h}}$ & $14.090 \pm 0.042^{\mathrm{h}}$ & $9.260 \pm 0.113^{\mathrm{cf}}$ & $11.340 \pm 0.099^{\mathrm{hj}}$ & Absent \\
\hline $\mathrm{P} 13$ & $17.890 \pm 0.057^{\mathrm{d}}$ & $15.840 \pm 0.127^{\mathrm{i}}$ & $11.710 \pm 0.071^{\mathrm{j}}$ & $12.540 \pm 0.084^{\mathrm{i}}$ & Absent \\
\hline
\end{tabular}




\begin{tabular}{cccccc}
\hline P14 & $22.515 \pm 0.064^{\mathrm{c}}$ & $16.520 \pm 0.056^{\mathrm{l}}$ & $12.370 \pm 0.113^{\mathrm{i}}$ & $12.870 \pm 0.042^{\mathrm{k}}$ & Absent \\
P15 & $17.135 \pm 0.148^{\mathrm{dh}}$ & $14.950 \pm 0.113^{\mathrm{m}}$ & $9.660 \pm 0.099^{\mathrm{c}}$ & $10.690 \pm 0.056^{\mathrm{g}}$ & Absent \\
P16 & $22.075 \pm 0.078^{\mathrm{c}}$ & $22.760 \pm 0.099^{\mathrm{f}}$ & $16.650 \pm 0.184^{\mathrm{a}}$ & $15.270 \pm 0.099^{\mathrm{e}}$ & Absent \\
P17 & $18.440 \pm 0.099^{\mathrm{g}}$ & $14.590 \pm 0.127^{\mathrm{hm}}$ & $9.810 \pm 0.099^{\mathrm{c}}$ & $11.230 \pm 0.084^{\mathrm{hj}}$ & Absent \\
P18 & $19.880 \pm 0.085^{\mathrm{e}}$ & $16.820 \pm 0.085^{\mathrm{l}}$ & $11.300 \pm 0.113^{\mathrm{k}}$ & $11.580 \pm 0.113^{\mathrm{j}}$ & Absent \\
P19 & $21.550 \pm 0.127^{\mathrm{b}}$ & $18.370 \pm 0.113^{\mathrm{n}}$ & $12.550 \pm 0.127^{\mathrm{i}}$ & $12.140 \pm 0.113^{\mathrm{i}}$ & Absent \\
P20 & $19.535 \pm 0.064^{\mathrm{e}}$ & $19.680 \pm 0.156^{\mathrm{k}}$ & $13.080 \pm 0.085^{\mathrm{bi}}$ & $12.510 \pm 0.070^{\mathrm{i}}$ & Absent \\
P21 & $21.120 \pm 0.085^{\mathrm{b}}$ & $20.220 \pm 0.056^{\mathrm{o}}$ & $14.210 \pm 0.127^{\mathrm{d}}$ & $13.100 \pm 0.028^{1}$ & Absent \\
Means & $19.690 \pm 2.781$ & $17.489 \pm 3.531$ & $12.073 \pm 2.862$ & $12.398 \pm 1.769$ & Absent \\
\hline \multicolumn{7}{c}{ Mean values with the same letter on the same line and in the same column are not significantly different at the }
\end{tabular}

Table.4 Mean values in CFU/mL of the germs counted in the samples of water during the period of flood

\begin{tabular}{|c|c|c|c|c|c|}
\hline Points & $\begin{array}{l}\text { Total mesophilic } \\
\text { flora }\left(\mathbf{1 0}^{8}\right)\end{array}$ & $\begin{array}{c}\text { Total coliforms } \\
\left(\mathbf{1 0}^{5}\right)\end{array}$ & $\begin{array}{l}\text { Thermotolerant } \\
\text { coliforms }\left(10^{5}\right)\end{array}$ & $\begin{array}{c}\text { Staphylococcus } \\
\left(\mathbf{1 0}^{3}\right)\end{array}$ & Salmonella/25mL \\
\hline P1 & $35.290 \pm 0.099^{\mathrm{a}}$ & $28.610 \pm 0.127^{\mathrm{a}}$ & $22,610 \pm 0,156^{\mathrm{a}}$ & $31.610 \pm 0.056^{\mathrm{a}}$ & Absent \\
\hline $\mathbf{P 2}$ & $30.665 \pm 0.148^{b}$ & $24.415 \pm 0.219^{b}$ & $17,615 \pm 0,078^{b}$ & $29.900 \pm 0.028^{\mathrm{b}}$ & Absent \\
\hline P3 & $32.005 \pm 0.219^{c}$ & $27.355 \pm 0.134^{\mathrm{c}}$ & $20,255 \pm 0,134^{c}$ & $30.500 \pm 0.084^{\mathrm{c}}$ & Absent \\
\hline P4 & $27.465 \pm 0.106^{\mathrm{d}}$ & $14.365 \pm 0.106^{\mathrm{d}}$ & $11,315 \pm 0,106^{\mathrm{d}}$ & $24.440 \pm 0.070^{\mathrm{d}}$ & Absent \\
\hline P5 & $34.120 \pm 0.099^{\mathrm{e}}$ & $25.110 \pm 0.085^{\text {be }}$ & $22,080 \pm 0,042^{\mathrm{e}}$ & $31.170 \pm 0.084^{\mathrm{e}}$ & Absent \\
\hline P6 & $29.345 \pm 0.177^{\mathrm{f}}$ & $27.345 \pm 0.177^{\mathrm{c}}$ & $20,245 \pm 0,035^{\mathrm{c}}$ & $30.110 \pm 0.042^{\mathrm{f}}$ & Absent \\
\hline P7 & $24.220 \pm 0.198^{g}$ & $16.370 \pm 0.127^{\mathrm{f}}$ & $9,270 \pm 0,127^{\mathrm{f}}$ & $22.500 \pm 0.113^{\mathrm{g}}$ & Absent \\
\hline P8 & $28.190 \pm 0.113^{h}$ & $19.550 \pm 0.099^{\mathrm{g}}$ & $12,340 \pm 0,099^{\mathrm{g}}$ & $22.910 \pm 0.042^{\mathrm{h}}$ & Absent \\
\hline P9 & $26.525 \pm 0.063^{\mathrm{i}}$ & $20.810 \pm 0.056^{\mathrm{h}}$ & $13,510 \pm 0,085^{\mathrm{h}}$ & $24.180 \pm 0.113^{\mathrm{d}}$ & Absent \\
\hline P10 & $25.870 \pm 0.056^{\mathrm{j}}$ & $17.535 \pm 0.134^{\mathrm{i}}$ & $10,885 \pm 0,078^{\mathrm{i}}$ & $23.590 \pm 0.028^{\mathrm{i}}$ & Absent \\
\hline P11 & $33.810 \pm 0.099^{\mathrm{e}}$ & $24.205 \pm 0.163^{b}$ & $17,130 \pm 0,127^{\mathrm{j}}$ & $26.470 \pm 0.056^{\mathrm{j}}$ & Absent \\
\hline P12 & $26.320 \pm 0.127^{\mathrm{i}}$ & $19.390 \pm 0.085^{\mathrm{g}}$ & $12,320 \pm 0,127^{\mathrm{g}}$ & $25.380 \pm 0.070^{\mathrm{k}}$ & Absent \\
\hline P13 & $27.440 \pm 0.127^{d}$ & $21.590 \pm 0.056^{\mathrm{j}}$ & $14,390 \pm 0,057^{\mathrm{k}}$ & $26.710 \pm 0.056^{\mathrm{j}}$ & Absent \\
\hline P14 & $32.380 \pm 0.156^{c}$ & $22.130 \pm 0.056^{\mathrm{k}}$ & $15,430 \pm 0,085^{1}$ & $27.180 \pm 0.099^{1}$ & Absent \\
\hline P15 & $26.685 \pm 0.063^{\mathrm{i}}$ & $19.525 \pm 0.148^{\mathrm{g}}$ & $12,475 \pm 0,078^{\mathrm{g}}$ & $24.390 \pm 0.084^{\mathrm{d}}$ & Absent \\
\hline P16 & $32.775 \pm 0.063^{\mathrm{k}}$ & $27.405 \pm 0.106^{\mathrm{c}}$ & $20,425 \pm 0,134^{\mathrm{c}}$ & $31.050 \pm 0.042^{\mathrm{e}}$ & Absent \\
\hline P17 & $28.430 \pm 0.127^{\mathrm{h}}$ & $19.375 \pm 0.148^{\mathrm{g}}$ & $12,780 \pm 0,085^{\mathrm{g}}$ & $28.210 \pm 0.070^{\mathrm{m}}$ & Absent \\
\hline P18 & $29.900 \pm 0.170^{\mathrm{f}}$ & $21.990 \pm 0.099^{1}$ & $14,970 \pm 0,127^{1}$ & $28.760 \pm 0.099^{n}$ & Absent \\
\hline P19 & $31.700 \pm 0.156^{\mathrm{c}}$ & $23.615 \pm 0.177^{\mathrm{b}}$ & $16,665 \pm 0,106^{\mathrm{j}}$ & $29.180 \pm 0.042^{\circ}$ & Absent \\
\hline P20 & $29.280 \pm 0.127^{\mathrm{f}}$ & $24.330 \pm 0.085^{\mathrm{b}}$ & $24,330 \pm 0,085^{\mathrm{b}}$ & $29.780 \pm 0.056^{\mathrm{b}}$ & Absent \\
\hline P21 & $30.850 \pm 0.184^{b}$ & $25.600 \pm 0.255^{\mathrm{e}}$ & $18,700 \pm 0,113^{\mathrm{m}}$ & $30.190 \pm 0.070^{\mathrm{c}, \mathrm{f}}$ & Absent \\
\hline Means & $29.564 \pm 3.073$ & $22.413 \pm 3.911$ & $15.844 \pm 3.892$ & $27.533 \pm 2.991$ & Absent \\
\hline Norms & $10^{4}$ & $5.10^{2}$ & $2.10^{2}$ & 10 & Absent $/ 25 \mathrm{~mL}$ \\
\hline
\end{tabular}

Mean values with the same letter on the same line and in the same column are not significantly different at the $5 \%$ level. Data represents in table is mean of three replications. \pm Standard deviation

The presence of staphylococcus (pathogen) at high concentrations in the lake water confirmed the high prevalence of diarrheal diseases and skin diseases reported by health workers lake communities as highlighted Dovonou et al., (2011) on Lake Nokoué.

In conclusion, the study assesses the bacteriological water quality of the lake 
Ahémé. It appears that the Ahémé lake is heavily polluted and its waters carry significant microbial charges especially bacteria, witness for fecal pollution and which are not consistent with standards. The main sources of pollution of the lake from waste are resulting from human activities of the local population (household waste discharges, biomedical waste, leaching, and discharges of domestic wastewater). This pollution of the lake can affect the microbiological quality of fish products they offer. It falls to the Beninese public authorities to undertake urgently a reorganization plan for the lake and this by:

- Purifying discharges from storm water drainage collectors from the surrounding areas of the lake;

- Organizing information campaigns, education and awareness of the local population with good attitudes and hygiene practices for better management of the lake;

- Building more latrines and public showers for these populations;

- The implementation of a wastewater treatment system, waste and domestic waste on the lake.

These actions will improve the quality of the lake water so that fish products and will also help prevent the epidemiological episodes due to recurrent water borne diseases especially in rainy seasons, periods of high unhealthy.

\section{References}

Abou, Y. 2001. Effet d'une couverture d'Azolla LAM sur la production piscicole du tilapia Oreochromis niloticus (L.) en étangs dans la banlieue de Cotonou (Bénin). Mémoire d'études complémentaires en éco-technologie des eaux continentales. Faculté des Sciences. Facultés Universitaires Notre Dame de la Paix. Belgique. 85p.

Adigun, A.E.N. 2013. Caractérisation microbiologique et physico-chimique des eaux et produits de pêche au Bénin: Cas des lacs Nokoué et Ahémé et de la lagune de Porto-Novo. Mémoire de Master. FAST/UAC. Bénin. 73p.

Adjahouinou, D.C., Yèhouénou, B., Liady, M.N.D., Fiogbé, E.D. 2014. Caractérisation bactériologique des eaux résiduaires brutes de la ville de Cotonou. J. Appl. Biosci., 78: 6705-6713.

Agonkpahoun, E. 2006. Evaluation de la pollution des eaux continentales par les métaux toxiques : Cas de la rivière Okpara et du lac Nokoué au Bénin. Thèse de Doctorat. Université d'Abomey-Calavi. Bénin. 87p.

Dédjiho, C.A. 2014. Etude diagnostique de la pollution chimique des plans d'eau du complexe lagunaire du Sud-Ouest du Bénin : Cas du lac Ahémé-gbézoumè. Thèse de Doctorat. Université d'Abomey-Calavi. Bénin. 125p.

Dègnon, G.R., Dahouénon-Ahoussi, E., Adjou, E.S., Ayikpé, O., Tossou, S., Soumanou M.M., Sohounhloué, D.C.K. 2012. Impact des traitements postcapture sur la qualité microbiologique des crevettes (Penaeus spp) du lac Ahémé au Bénin destinées à l'exportation. J. Appl. Biosci., 53: 3749 $-3759$.

Dimon, F., Dovonou, F., Adjahossou, N., Chouti, W., Mama, D., Alassane, A., Boukari, M. 2014. Caractérisation physico-chimique du lac Ahémé (Sud Bénin) et mise en relief de la pollution des sédiments par le plomb, le zinc et l'arsenic. J. Soc. Ouest-Afr. Chim., 37: 36-42.

Dovonou, F., Aïna, M., Boukari, M., Allassane, A. 2011. Pollution physico- 
chimique et bactériologique d'un écosystème aquatique et ses risques écotoxicologiques : cas du lac Nokoué au Sud Bénin. Int. J. Biol. Chem. Sci., 5(4): 1590-1602.

Guiraud, J., Galzy, P. 1980. L'analyse dans les industries agroalimentaires. Collection Génie alimentaire, Edition de l'usine nouvelle, Paris. 240p.

Mègnon, G.T., Soumanou, M.M., Tossou, S., Mensah, G.A. 2012. Evaluation de la qualité sanitaire des crevettes (Penaeus spp) du Lac Nokoué au Sud-Bénin : Aspects chimique et microbiologique. Bulletin de la Recherche Agronomique du Bénin (BRAB), Numéro spécial Elevages de gibier \& non gibier. 24-30.

NF ISO 4833 (V 08-051). 2003. Microbiologie des aliments, Méthode horizontale pour le dénombrement des micro-organismes. Technique de comptage des colonies à $30^{\circ} \mathrm{C}$ sur PCA. $19 \mathrm{p}$.

NF ISO 4832 (V 08-015). 2006. Microbiologie des aliments, Méthode horizontale pour le dénombrement des coliformes. Méthode par comptage des colonies obtenues à $37^{\circ} \mathrm{C} .6 \mathrm{p}$.

NF ISO4832 (V08-060). 2009. Microbiologie des aliments, Dénombrement des coliformes thermotolérants par comptage des colonies obtenues à $44^{\circ} \mathrm{C}$. Biokar diagnostics Violet Red Bile Agar (VRBA). 4p.
NF ISO 4834 (NFV 08-057-1). 2006. Microbiologie des aliments, Méthode horizontale pour le dénombrement des staphylocoques. Méthode par comptage des colonies obtenues à $37^{\circ} \mathrm{C}$ sur Baird Parker. 8p.

NF ISO 6579. 2002. Microbiology of food and animal feeding stuffs, Horizontal method for the detection of Salmonella spp. Fourth edition. $34 \mathrm{p}$.

Niyonkuru, C., Lalèyê, P. 2012. Comparative ecological approach of the lenght-weight relationships and condition factor of sarotherodon melanotheron Rüppell, 1852 and Tilapia guineensis (Bleeker 1862) in lakes Nokoué and Ahémé (Benin, West Africa). Int. J. Business, Humanities and Technol., 2(3): 41-50.

Sachi, S.P.A., Bokossa Yaou, I., Tchekessi, C.K.C., Djogbè, A.A., Banon, S.J.B., Blèoussi, R., Mensah, G.A. 2016. Evaluation de la connaissance et de la mise en œuvre des bonnes pratiques d'hygiène par les populations riveraines du lac Nokoué (Sud-Bénin). Int. J. Biol. Chem. Sci., 10(4): 1823-1831.

Sachi, S.P.A. 2015. Carte du lac Ahémé avec les points de prélèvement des échantillons d'eau. Bénin, Octobre 2015.

Servais, P., Billen, G., Garcia-Armisen, T., George, I., Goncalvez, A., Thibert, S. 2010. La contamination microbienne des eaux du bassin de la Seine. Ecologie des Systèmes Aquatiques, Université Libre de Bruxelles, Belgique. 35p.

\section{How to cite this article:}

Pivot S.A. Sachi, Innocent Yaou Bokossa, Célestin C.K. Tchekessi, Roseline M. Bleoussi, Jultesse S.B. Banon, Anayce A. Djogbe, Karl Assogba and Guy A. Mensah. 2016. Assessment of the Bacteriological Quality of an Aquatic Ecosystem in South of Benin: Case of Ahémé Lake. Int.J.Curr.Microbiol.App.Sci. 5(11): 379-387. doi: http://dx.doi.org/10.20546/ijcmas.2016.508.043 